I have. A copy was sent to Messrs. Groombridge in support of certain claims on my views about the stars. Let me hasten to assure Prof. Reynolds that, as he surmises, the views expressed in this very scarce treatise bear not the remotest resemblance to his.

I read several weeks ago Prof. Reynolds' interesting paper, the views expressed in which are, in a general way, similar to those $I$ advocated in a paper entitled "Strange Discoveries respecting the Aurora" in Frazer's Magazine for February 1870. As it was quite clear to me, however, that Prof. Reynolds' views had been formed quite independently, it scemed wholly unnecessary to comment on that resemblance. I could only rejoice that so competent an authority should have been led to conclusions agreeing in general so satisfactorily with those $I$ had deduced; and also, be it noted, with the results of the observations made on the recent eclipse.

\section{Browning's Spectroscope}

A LETTER from Mr. Browning, in the number of NATURE for December I5th, has just come to my notice, and seems to require a word from me. I regret exceedingly that he should have supposed that I intended to imply that he had committed any impropriety in employing in his own automatic combination an arrangement of Mr. Rutherfurd's from a spectroscope which was not automatic. I did not "go out of my way" in making the allusion, but only stated what $I$ supposed to be a fact, in orcler to show that the proposed arrangement of radial bars was good and practicable, having already been endorsed by most eminent authority.

At the time when the article was written, Mr. Browning had but recently published the account of his instrument, arid, of course, I knew nothing about its earlier history.

On the other hand, a full description of Mr. Rutherfurd's arrangements with an illustrative figure had appeared in Silliman's Fournal in March 1865 , more than four years earlier. 'This article is dated December' 10 , 1864 , and will be found in the Journal referred to: vol. xxxix., p. I29.

Possibly the tone of my allusion may have been unintentionally affected by the fact that I supposed that Mr. Browning had seen this article. In common with many other Americans, who have spoken to me about it, I thought it singular that, in describing his own instrument, he made no reference to $\mathrm{Mr}$. Rutherfurd, and am very happy to find him blameless in the matter. At the same time, I think he has no ground of complaint against me for referring to the arrangement as "first devised by $\mathrm{Mr}$. Rutherfurd, and since adopted by Mr. Browning;" although, if were to write the sentence again with my present knowledge of the facts, I should put it quite differently.

Let me add also that, having seen the instrument to which $\mathrm{Mr}$. Lockyer refers in his note, I cheerfully concede to him the priority in respect to the use of an elastic spring, and the half prism at the beginning of the train, as well as the idea of sending the light twice through the train by a right-angled prism at its extremity. As he has never published an account of his instrument, however, I suppose I can hardly be held blamewoithy for re-in. venting it, and publishing it myself. Without one unkindly feeling the words of the old poet still sometimes come to nind, "Fereant qui ante nos nostra dixerint."

The magnetic record at Greenwich shows a well-marked disturbance of all the elements precisely simultaneous with the eruption observed on the sun's disc September 28th. The declination was affected to the extent of five minutes of arc, and the disturbance was compounded of two waves, following each other, and partly superposed, probably corresponding to the ejection of the two masses of protuberance-matter which are show in the figures.

London, Jan. 21, 1871

\section{St. Mary's Hospital}

I SEE in this week's NATURE the announcement that Dr. Wood has been appointed Lecturer on Chemistry at St. Mary's Hospital Medical School. This is an entire mistake; no appointment has yet been made, since Dr. Russell will continue to hold the post until the end of the Winter Session. The vacancy has not therefure actually occurred yet, although it will be declared shortly, and a fresh appointment made in due course. W. B. CHEADLE,

Dean of St. Mary's Hospital Medical School

Jan. 20

[We were misled in maling the announcement referred to above by our contemporary the British Meaical Fournal.-ED.]

\section{IMPROVEMENT OF GEOMETRICAL} $T E A C H I N G$

A CONFERENCE was held at University College, London, on Tuesday, the 17 th inst., to take this subject into consideration, and to form an Association for the improvement of geometrical teaching throughout the United Kingdom.

Previous to the meeting a large number of head and mathematical masters and others interested in the subject had given in their adhesion to the principles upon which it was proposed to form the Association. These included representatives of the following important schools:Winchester, Eton, Harrow, Rugby, Charterhouse, Christ's Hospital, Marlborough, Wellington, Clifton, Uppingham, Sherborne, Birmingham, Dulwich, University College School, London, Repton, Durham, Manchester, King William's College, Isle of Man ; Tiverton, Taunton, Leeds, Huddersfield, Nottingham, Yarmouth, Windermere, Millhill School, Middlesex, Middle Class School, Cowper Street, Middle Class School, Bedford, the majority of whom were present at the Conference. The movement was further supported by Dr. Hirst, F.R.S., of London University, Mr. W. Spottiswoode, F.R.S., president of the London Mathematical Society, Mr. C. W. Merrifield, F.R.S., Principal of the Royal School of Naval Architecture, South Kensington, and others.

Dr. Hirst, the president, took the chair, and resolutions were passed bearing upon the organisation and future working of the Association. It was proposed to invite the mathematicians of the country to prepare syllabuses of elementary geometry, embodying their views of tiie principles which should be adopted in any new text-book which is 10 supersede Euclid. Further particulars may be obtained by application to Mr. R. Levett, honorary secretary, King Edward's School, Birmingham.

\section{A HINT TO ELECTRICIANS}

M R. MANCE'S method for measuring the internal resistance of a single galvanic element or battery, communicated to the Royal Society at its meeting of last week, and the modifications of Wheatstone's bridge suggested by myself for finding the resistance of a galvanometer coil from the deflection of its own needle, supply desiderata in respect to easy and rapid measurement, which have been long felt by telegraph electricians and needed by other scientific investigators and by teachers of science. Year after year the latter, in their arrangement of batteries, electrodes, and galvanometers, have darkly and wastefully followed the method which from workmen we learn to call rule of thumb; while the former, with admirable scientific art, measure every element with which they are concerned, in absolute measure. How many physical professors are there in Europe or America who could tell (in millions of centimetres per second) the resistance of any one of the galvanometers, induction coils, or galvanic elements which they are daily using? How many of them, in ordering an electro-magnet, require of the maker that the specific resistance of the copper shall not exceed 16,000 (gramme centimetre-seconds)? How many times have eight Grove cells been set up to produce a degree of electro-magnetic effect which four would have given, had the professor exacted of the instrumentmaker the fulfilment of a simple and inexpensive scientific condition, as submarine telegraph companies have done in their specifications of cables ? If every possessor of an electro-magnet were to cut a metre off its coil, weigh the piece, measure its resistance, and send the result to NATURE, and if every maker of Rubmkorff coils would do the like for every coil of copper wire designed for his instruments, a startling average might be shown. And what of the items? I venture to say that (provided the instruments of the great makers are not excluded) specific 